\title{
Impact of Safety Factors on Construction Workers' Performance
}

\author{
Amani M. Al Hadidi, ${ }^{1, *}$, Osama T. Al Meanazel ${ }^{2}$ \\ ${ }^{1}$ Department of Allied Engineering Sciences, Engineering Faculty, Hashemite University, Al Zarqa, 13133, Jordan \\ ${ }^{2}$ Department of Industrial Engineering, Engineering Faculty, Hashemite University, Al Zarqa, 13133, Jordan
}

Received March 28, 2021; Revised April 29, 2021; Accepted June 15, 2021

\section{Cite This Paper in the following Citation Styles}

(a): [1] Amani M. Al Hadidi, Osama T. Al Meanazel, "Impact of Safety Factors on Construction Workers' Performance," Civil Engineering and Architecture, Vol. 10, No. 2, pp. 682-691, 2022. DOI: 10.13189/cea.2022.100223.

(b): Amani M. Al Hadidi, Osama T. Al Meanazel (2022). Impact of Safety Factors on Construction Workers' Performance. Civil Engineering and Architecture, 10(2), 682-691. DOI: 10.13189/cea.2022.100223.

Copyright $\bigcirc 2022$ by authors, all rights reserved. Authors agree that this article remains permanently open access under the terms of the Creative Commons Attribution License 4.0 International License

\begin{abstract}
This study analyzed the factors of the Occupational Health and Work Safety (OHS) implementation and Risk Management (RM) implementation that affect the performance of site construction workers. It also examined the mediation role of RM between OHS and site construction workers' performance. A quantitative [1] survey method of self-distributing questionnaires was employed using simple random sampling of 600 site construction workers on a site-widening project in Jordan, with a $99 \%$ response rate. The results of the questionnaire [1] were used and analyzed for the validity test, reliability, f-test, and t-test for each item of statement. The method of analysis [1] used for testing the hypothesis is Partial Least Square-Structure Equation Modeling (PLS-SEM) which utilized AMOS for the descriptive analysis test results. The results of this study show that the Work Safety (WS) variable was the most dominant element as there are $82 \%$ of health and safety devices in my workplace. However, in case of any [1] accident on the construction site, there was $81 \%$ of the practical result of the Occupational Health variable which was Emergency treatment. The dominant result was Workers [7] for the RM variable assigned for likely hazardous or serious tasks, which was $87 \%$ and controlled regularly by the internal audits for testing if they follow the set of procedures and instructions for the safety and health of the workers in my organization. The results of PLS-SEM concluded that the [0] implementation of OHS and RM had a positive and significant effect on the performance of site construction workers. Moreover, the RM plays a partial mediation role between Site Construction Workers'
\end{abstract}

Performance and OHS. [1] The findings show that the application of OHS in the construction projects affects the achievement of the company's work.

Keywords COVID-19, Personal Protective Equipment [PPE), Construction Sites Projects, Worker Attitudes, Work Targets

\section{Introduction}

Improving workers' performance is usually understood as the systematic process of discovering and analyzing important human performance gaps and planning for future worker performance [1]. The performance of construction worker sites is a significant tool that is necessary to complete and manage projects successfully with low efforts and costs [2]. Many factors affect the performance of construction workers, most importantly the OHS implementation. OHS is critical and the most important factor for the improvement of the construction site workers' performance $[3,4]$ because construction sites include various levels of risk and danger. On all sites, the priority that ought to be concerned is to keep the workers safe; especially with regard to the fact that the conditions of the site can be changed quickly and unexpectedly involves risks. Thus, accidents can happen and cause fatalities or injuries of the workers, which leads to a delay or suspension of the work and a decrease in the productivity according to the employees. Subsequently, 
the company and the project will be in serious financial risks due to the costs required to solve the matter $[5,6]$. [25] The maintenance of the highest degree of physical, mental, and social well-being of workers in all occupations should be promoted by the WS and the occupational health [7]. Safety protects the construction site workers from the risks that cause injuries and that can happen due to unplanned accidents, which leads to property and human damage [8]. RM is another critical factor that affects construction workers' performance in the industry, which is the main part of the management and planning of the project. RM is considered as an instrument that helps in dealing with various risks and remedial steps and their analyses to avoid such risks $[9,10]$.

\section{Problem Statement in Construction Industry in Jordan}

The construction industry sector in Jordan is critical and includes several risks, especially in sites:

1. Lack of sensitivity from the company regarding the importance of workers' OHS on a project under the company auspices [11-13].

2. Lack of attention from the company for providing better equipment and services that related to safety of the work as the main principle of all the objectives of the project [11-15].

3. Lack of understanding from workers of the risks regarding OHS [13-16].

4. Workers' lack of safety information about site construction [13-16]

This study sought to confirm the implementation of OHS and RM in Jordan, the following problem formulation for the construction site worker in Jordan:

1. What are the factors of implementing OHS that affect the workers' performance?

2. What are the factors of RM that affect the performance of workers?

3. How does the implementation of OHS affect the performance of workers?

4. How does the implementation of RM affect the performance of workers?

5. Does RM play a mediation role between the implementation of $\mathrm{OHS}$ and the performance of construction site workers in Jordan?

\section{Literature Review}

Previous research [13-16] discussed the relations between the implementation of OHS and RM and the performance of workers in the manufacturing industry, electricity companies, and general services. Few of them were applied in Jordan, and none discussed the critical part, i.e., sites construction workers. Dababneh [13] found that there is a negative effect influence between the use of OHS and the performance of worker and showed a lack of the implementation of OHS in Jordan. However, Alubaid [17] found that the use of OHS of the quality of productivity increased critical problem in Jordan which has no attention by the company, and it should provide better equipment and services that are related to the safety of its workforce as the main objective of the project. Abbas [14] discussed the factor that affected the use of OHS and found no understanding by the workers of the risks concerning OHS. However, there are few studies in RM in [15] the construction industry in Jordan. Panel Atallah [16] stated that no sensitivity from a company concerning the value of workers' implementation of RM on a project under the company auspices shows that there is a positive influence between RM implementation and the performance of workers.

No previous studies discussed the relations between the implementation of OHS and RM and the performance of workers in construction site in Jordan. Moreover, no previous research examined the mediation role of RM between the performance of site construction workers and OHS. The researchers' knowledge can be enriched about the OHS and RM programs that are used in the workers' productivity and performance. In addition, it is important to know more about the influences of OHS, work safety, and RM, and the performance of the workers is contradictory either directly or indirectly (mediation). Similar to previous reviews, this study employed the same variables which could test the effect of OHS on workers' performance. The hypothesis formed (Figure 1) are as follows:

\section{First hypothesis: $\mathrm{H} 1$}

H1a - work safety (WS) has a positive and significant $[0]$ influence on workers' performance

H1b: OHS has a positive and significant influence on workers' performance.

Second hypothesis: $\mathrm{H} 2$

$\mathrm{H} 2 \mathrm{a}$ - WS has a positive and significant influence on RM.

$\mathrm{H} 2 \mathrm{~b}$ : OHS has a positive and significant influence on $\mathrm{RM}$.

Third hypothesis: $\mathrm{H} 3$

H3: RM has a positive and significant influence on workers' performance

Fourth hypothesis: $\mathrm{H} 4$

H4a: RM plays a mediation role between WS and workers' performance.

H4b: RM plays a mediation role between occupational health and workers' performance. 


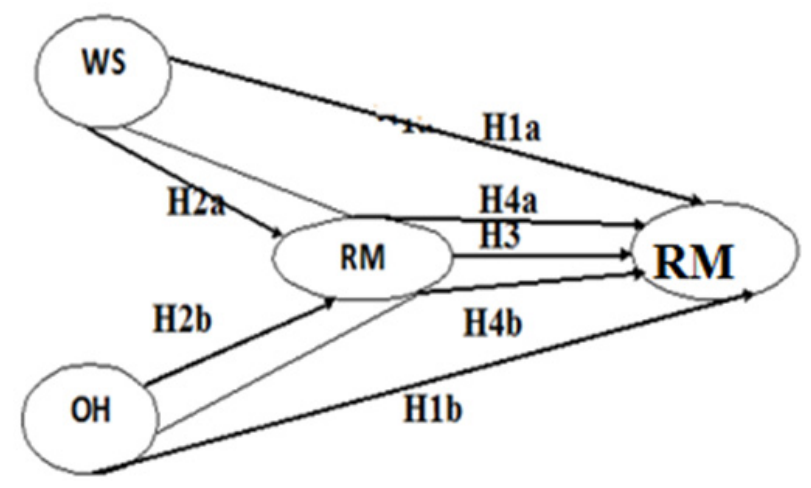

Figure 1. Conceptual Framework and Hypothesis Research

\section{Aims and Approaches}

The aims of this study are to:

- Investigate the factors of OHS implementation that affect the performance of site construction workers.

- Identify the effect of RM implementation on the performance of site construction workers.

- Examine the mediation role of RM between the performance of site construction workers and OHS.

\section{Methodology}

This section discusses the research methods used to analyze OHS and RM implementation factors that affect the performance of workers on the construction sites in Jordan. The methods used in this study are original and not adapted from existing ones. The research strategy determines to obtain the data needed in advance. The following aspects that affect the type of procedure are used in this study:

a) The type of statement used

b) Control of the events under the study; and

c) Focus on current events.

\subsection{Research Design}

Based on the problem formulation and objectives of the research, the descriptive and verification analysis methods were the design used. Thus, the descriptive analysis method is a statistic used to analyze the collected data, and verification applied for testing hypotheses by statistical test equipment [20]

\subsection{Population and Sampling}

A generalization area that includes subjects or objects having specific characteristics and qualities determined by the researchers for conducting studies and drawing conclusions is known as the population [21].

In this study, the population was all the 600 workers from the construction project sites in Amman, Jordan
Regency. In addition, the sampling method is used for determining the sample of this research [20]. A percentage error of $5 \%=0.05$ is used and, the sample size is calculated by the Slovein technique. [1] mentioned the following:

$$
n=N / 1+N e^{2}
$$

Sample Size $=\mathrm{n}$

Percent deviation for inaccuracy due to error $=\mathrm{e}$

Population Size $=$ N (e.g., project workers)

Accordingly, the number of samples to be examined $=\mathrm{n}$

$$
\begin{gathered}
\mathrm{n}=600 /\left(1+600(0.05)^{2}\right) \\
\mathrm{n}=240 \text { people }
\end{gathered}
$$

\subsection{The Validity Test}

In this study, the validity is used to find out if the questionnaire which is the measuring instrument can carry out its functions. The statement is declared valid if the correlation is greater than or equal to 0.30 .

\subsection{A Reliability Test}

Reliability of the measuring instrument can provide the same results when used repeatedly, with not much difference. Also, the statistical approach is done by SPSS and used for measuring the reliability by coefficient; if it is greater than 0.60 , the whole statement is declared to be reliable. Thus, the percentage of the average value of each indicator is displayed by performing a descriptive analysis. Thus, the implementation of OHS and RM is described at the company with the level of workers' performance

\subsection{Methodological Approach}

The method used in this research was descriptive research, and the type was quantitative research. Descriptive study is used for determining the value of independent variables as connected or compared with other variables, while quantitative research is used for obtaining data as compiled qualitative data or in the form of numbers [20].

The workers' population in the Jordan Construction Project was 240. In this study, the sampling technique was carried out by incidental sampling method. Questionnaire distribution techniques involved construction projects to disseminate questionnaires or distribute them directly to construction workers on the project who are ready to work together and be used as data sources. The number of workers sampled to reach the final goal of the research was 240 , and the data needed are primary and secondary data.

Data used to focus on the effect of the use of OHS and RM [14] on employees' performance was the primary data, while the data used to support research data presentation is the secondary data [20]. 


\section{Primary Data}

- Data were obtained from observations, group subject opinions, and individual or physical activities or events. Also, primary data used the survey method to obtain the data, and the survey method used written statement in a central data collection

- The necessary data can be obtained by making relations between the subject and the researcher (respondent).

- The design of collecting the data is for expressing ideas and solving causes and effects, and the data are mostly descriptive.

- The data from several subjects were used for having the same data.

- The distributing questionnaire is used for conducting interviews.

\section{Secondary Data}

Secondary data was obtained from literature and media related to the object under study.

\subsection{Variable Operational Definition}

According to Sugiyono [20], the notion of a research [14] variable is an attribute, trait, or value of people, objects or activities having individual variations determined by researchers to be studied, and conclusions could be drawn. In this study, there are four variables and indicators as shown in Table 1.

Work Safety required in a job to guarantee the welfare of working life (X2)

Occupational Health means a prosperous condition of the body, soul, and social relation, allowing a person to live productively, socially, and economically (X1).

$\mathrm{RM}$ is an instrument that helps in dealing with various risks and remedial steps and their analyses to avoid it $(Z)$

Worker's performance is the result or level of an optimal person in carrying out the task or work (Y).

Table (1) below shows the variables and indicators that [3] were used in this study based on previous research $[18,19]$.

\subsection{Data Collection Technique}

\section{a) Secondary Data Collection [10]}

Collecting data on the number of workers involved, contract plans, tool box meetings on construction projects, print media relating to construction projects, several references to research results, and other data related to Quality Control.

\section{b) Primary Data Collection}

Primary data is collected by questionnaire distribution method where respondents will be asked to answer questions, which will then make a tabulation of their assessments.

\subsection{Data Measuring Tool}

All variables used in this study were measured using a [3] Likert Scale. In this case, the author assumes that the Likert scale produces variable measurements in the Interval Scale. There are five measurement alternatives used, namely the Likert Scale type with a score as shown in Table 2.

Table 1. Variables and indicators

\begin{tabular}{|c|c|c|c|c|}
\hline & $\begin{array}{r}\text { Occupational Health }(x \\
\text { Work safety }(\mathrm{x} 2) \mathrm{v}\end{array}$ & $\begin{array}{l}\text { ariable } \\
\text { ble }\end{array}$ & Risk Management (Z) variable & $\begin{array}{l}\text { worker performance }(\mathrm{Y}) \\
\text { variable }\end{array}$ \\
\hline 1 & $\begin{array}{c}\text { COVID } 19 \text { spreading :indicator } \\
\text { (X11) }\end{array}$ & \multirow{4}{*}{$\begin{array}{l}\text { Occupational } \\
\text { Health }(\mathrm{x} 1)\end{array}$} & $\begin{array}{c}\text { Errors in designs and } \\
\text { specifications :indicator (Z1) }\end{array}$ & $\begin{array}{c}\text { Prioritizing } \\
\text { :indicator (Y1) } \\
\end{array}$ \\
\hline 2 & $\begin{array}{c}\text { First aid, accident management : } \\
\text { indicator (X12) }\end{array}$ & & Lack of training: indicator (Z2) & $\begin{array}{c}\text { Skills } \\
\text { :indicator (Y2) }\end{array}$ \\
\hline 3 & $\begin{array}{l}\text { Medical examination : indicator } \\
\text { (X13) }\end{array}$ & & $\begin{array}{l}\text { safety procedure risk: indicator } \\
(\mathrm{Z} 3)\end{array}$ & $\begin{array}{c}\text { Ability } \\
\text { :indicator (Y3) }\end{array}$ \\
\hline 4 & Health care : indicator (X14) & & Stockholder risk : indicator (Z4) & $\begin{array}{c}\text { Quantity and quality work } \\
\text { :indicator (Y4) }\end{array}$ \\
\hline 5 & Work load : indicator (X21) & \multirow{4}{*}{ Work safety(x2) } & Environmental risk: indicator (Z5) & $\begin{array}{l}\text { working hours } \\
\text { :indicator }(\mathrm{Y} 5)\end{array}$ \\
\hline 6 & Curative services : indicator (X22) & & Utilities risk : indicator (Z6) & $\begin{array}{l}\text { Timeliness } \\
\text { :indicator (Y6) }\end{array}$ \\
\hline 7 & $\begin{array}{l}\text { Work safety equipment : indicator } \\
\text { (X23) }\end{array}$ & & Site access risk : indicator (Z7) & $\begin{array}{l}\text { Work equipment } \\
\text { :indicator (Y7) }\end{array}$ \\
\hline 8 & $\begin{array}{c}\text { Quality assurance of } \mathrm{OH} \\
\text { processes, audits: indicator (X24) }\end{array}$ & & Security risk: indicator (Z8) & $\begin{array}{c}\text { Knowledge } \\
\text { :indicator (Y8) }\end{array}$ \\
\hline
\end{tabular}

Table 2. Likert scale

\begin{tabular}{|c|c|c|c|c|c|}
\hline Likert scale & Strongly disagree & Disagree & Neutral & Agree & Strongly agree \\
\hline Score & 1 & 2 & 3 & 4 & 5 \\
\hline
\end{tabular}




\subsection{Data Analysis Technique}

An associative analysis and descriptive approach are employed to determine the causal relationship with the survey approach. This is done by focusing on the variables for presenting a factual, structural, and exact explanation of the relationships and facts between the variables. SPSS is used, and the data analyzed the collected respondents [20]. Furthermore, it includes grouping data that depend on the types of respondents and variables. The validity and reliability are tested.

The quantitative approach, the Partial Least Squares (PLS) - Structural Equation Modeling (SEM) analyses, was used in this research to test the hypotheses. SEM is a model way for studying the relationship between potential factors, including latent and observable variables, which cannot be observed directly. At the same time, it can deal with many dependent variables and overcome the disadvantage of single dependent variable in linear correlation analysis. In addition, SEM can reflect the entire data systematically and objectively for reducing the deficiency in the questionnaire which is more qualitative than quantitative. Thus, when the first-order dimension for studying the causal structure contact and intensity is introduced between the second-order constructs, which helps in having the mathematical model and quantitative law behind the subjective value [22].

PLS analysis is a multivariate statistical technique that allows the comparison between multiple response variables and multiple explanatory variables. PLS is one of a number [6] of covariance-based statistical methods which are often referred to as structural equation modeling or SEM. SEM analyses are applied when there are several independent variables (at least two or more). This is [23] conducted by AMOS for examining the effect of the independent variables on the dependent variables either collectively or partially [23]

\section{Results and Discussion}

\subsection{Summery Demographic Information}

The sample of this study is the employees in different construction sites in Amman city in Jordan. Table 3 summarizes the demographic information of the population. The result shows that $72 \%$ of respondents are males and $28 \%$ are females. Moreover, the result shows that $61 \%$ of the respondents are aged from 17 to 37 years old compared to $37 \%$ are aged from 37 to 60 years old and $2 \%$ are those having other ages. In addition, it shows the work experiences character; $57 \%$ have an experience of 0 to 1 year, $41 \%$ have an experience of 10 to 20 years, and $2 \%$ have other years of experience. Besides, $12 \%$ has high school level of education, $81 \%$ has a BSC, and $7 \%$ has high education.

Table 3. Summarizing Demographic Information

\begin{tabular}{|c|c|c|}
\hline \multicolumn{2}{|c|}{ Factor -demographic characterizes } & Percentage \\
\hline \multirow{2}{*}{ Gender } & $\mathrm{M}$ & $72 \%$ \\
\cline { 2 - 3 } & $\mathrm{F}$ & $28 \%$ \\
\hline \multirow{3}{*}{ Age(Years) } & $17-37$ & $61 \%$ \\
\cline { 2 - 3 } & $37-60$ & $37 \%$ \\
\hline \multirow{2}{*}{$\begin{array}{c}\text { Work } \\
\text { experience(years) }\end{array}$} & High than 60 & $2 \%$ \\
\cline { 2 - 3 } & $1-10$ & $57 \%$ \\
\hline \multirow{2}{*}{\begin{tabular}{c} 
Education level \\
\cline { 2 - 3 }
\end{tabular}} & High than 20 & $41 \%$ \\
\cline { 2 - 3 } & High school & $2 \%$ \\
\cline { 2 - 3 } & BSC & $81 \%$ \\
\hline
\end{tabular}

\subsection{Validity and Reliability Tests}

To test questionnaires as a research instrument, the study used validity and reliability tests by SPSS. A validity test confirms whether the instrument used to obtain data in the study can be used or not, while the reliability test confirms whether the instrument will produce the same data in several times testing or to measure the same object. The validity test of the instrument in this study was conducted to find out whether the measuring instrument, which was a questionnaire, could carry out its functions. As explained in the research method, a statistical approach was employed through the correlation coefficient of the item's statement score with the total item's statement score; if the correlation coefficient is greater or equal to 0.30 , the statement is declared valid. The validity test was conducted to statement items related to all indicators after surveying through the distribution of questionnaires to 240 respondents in the construction project in Jordan. Then, the data containing the score of the statement items in the questionnaire were included in Table 4. Furthermore, the correlation value of each item to the total score was calculated. The results of the validity test are [7] shown in Table 4. The result shows that the correlation [11] coefficient of all statement in questionnaire is greater than 0.30 , then the statement is declared valid.

If the result shows that the questionnaire is valid and reliable, then it can be accepted as an instrument to measure the variables indicators 
Table 4. Test Validity of Research Indicators

\begin{tabular}{|c|c|c|c|c|}
\hline No. & indicator & $\begin{array}{c}\text { The correlation } \\
\text { coefficient ( } r \text {-count) }\end{array}$ & $r$-table value $(\alpha=1 \%)$ & Result \\
\hline 1 & COVID 19 spreading :indicator (X11) & 0.748 & 0.463 & Valid \\
\hline 2 & $\begin{array}{l}\text { First aid, accident management :indicator } \\
\text { (X12) }\end{array}$ & 0.790 & 0.463 & Valid \\
\hline 3 & Medical examination :indicator (X13) & 0.774 & 0.463 & Valid \\
\hline 4 & Health care :indicator (X14) & 0.800 & 0.463 & Valid \\
\hline 5 & Work load :indicator (X21) & 0.641 & 0.463 & Valid \\
\hline 6 & Curative services :indicator (X22) & 0.753 & 0.463 & Valid \\
\hline 7 & Work safety equipment :indicator (X23) & 0.601 & 0.463 & Valid \\
\hline 8 & $\begin{array}{l}\text { Quality assurance of } \mathrm{OH} \text { processes, audits: } \\
\text { indicator (X24) }\end{array}$ & 0.790 & 0.463 & Valid \\
\hline 9 & $\begin{array}{c}\text { Errors in designs and } \\
\text { specifications :indicator }(\mathrm{Z} 1)\end{array}$ & 0.641 & 0.463 & Valid \\
\hline 10 & $\begin{array}{l}\text { Lack of training } \\
\text { :indicator }(\mathrm{Z} 2)\end{array}$ & 0.621 & 0.463 & Valid \\
\hline 11 & $\begin{array}{l}\text { safety procedure risk } \\
\quad \text { :indicator }(\mathrm{Z} 3)\end{array}$ & 0.732 & 0.463 & Valid \\
\hline 12 & $\begin{array}{l}\text { Stockholder risk } \\
\text { :indicator }(\mathrm{Z} 4)\end{array}$ & 0.746 & 0.463 & Valid \\
\hline 13 & $\begin{array}{l}\text { Environmental risk } \\
\quad \text { :indicator (Z5) }\end{array}$ & 0.783 & 0.463 & Valid \\
\hline 14 & $\begin{array}{l}\text { Utilities risk } \\
\text { :indicator }(\mathrm{Z} 6)\end{array}$ & 0.824 & 0.463 & Valid \\
\hline 15 & $\begin{array}{l}\text { Site access risk } \\
\text { :indicator }(\mathrm{Z} 7)\end{array}$ & 0.692 & 0.463 & Valid \\
\hline 16 & $\begin{array}{c}\text { Security risk } \\
\text { :indicator }(\mathrm{Z} 8)\end{array}$ & 0.855 & 0.463 & Valid \\
\hline 17 & $\begin{array}{l}\text { Prioritizing } \\
\text { :indicator (Y1) }\end{array}$ & 0.876 & 0.463 & Valid \\
\hline 18 & $\begin{array}{c}\text { Skills } \\
\text { :indicator (Y2) }\end{array}$ & 0.823 & 0.463 & Valid \\
\hline 19 & $\begin{array}{c}\text { Ability } \\
\text { :indicator (Y3) } \\
\end{array}$ & 0.789 & 0.463 & Valid \\
\hline 20 & $\begin{array}{l}\text { Quantity and quality work } \\
\text { :indicator (Y4) }\end{array}$ & 0.657 & 0.463 & Valid \\
\hline 21 & $\begin{array}{l}\text { working hours } \\
\text { :indicator (Y5) }\end{array}$ & 0.786 & 0.463 & Valid \\
\hline 22 & $\begin{array}{c}\text { Timeliness } \\
\text { :indicator (Y6) }\end{array}$ & 0.831 & 0.463 & Valid \\
\hline 23 & $\begin{array}{l}\text { Work equipment } \\
\text { :indicator (Y7) }\end{array}$ & 0.737 & 0.463 & Valid \\
\hline 24 & $\begin{array}{c}\text { Knowledge } \\
\text { :indicator (Y8) }\end{array}$ & 0.688 & 0.463 & Valid \\
\hline
\end{tabular}

A reliability test was applied to find out whether the measuring instrument designed in the form of a questionnaire can be relied upon; a measuring instrument is reliable if it provides relatively the same results (not much different) when used repeatedly. A statistical approach is [3] used to determine whether a measure is reliable or not; it is done through the reliability coefficient. If the reliability [11] coefficient is greater than 0.60 , the whole statement is declared to be reliable. The reliability test technique used the alpha reliability coefficient. The decision-making criterion was that if the value of the alpha reliability coefficient is greater than 0.6 , the variable is reliable. The test results are shown in Table 5; [35] all variables have alpha reliability coefficient greater than
0.60 , hence the whole statement is declared to be reliable

Table 5. Reliability Test Research Indicators

\begin{tabular}{|c|c|c|c|}
\hline No. & Variable & $\begin{array}{c}\text { Alpha reliability } \\
\text { coefficient }\end{array}$ & Result \\
\hline 1 & Work Safety (X1) & 0.847 & Reliable \\
\hline 2 & $\begin{array}{c}\text { Occupational Health } \\
(\mathrm{X} 2)\end{array}$ & 0.891 & Reliable \\
\hline 3 & Risk Management (Z) & 0.821 & Reliable \\
\hline 4 & $\begin{array}{c}\text { Worker Performance } \\
\text { (Y) }\end{array}$ & 0.847 & Reliable \\
\hline
\end{tabular}

\subsection{Descriptive Analysis}

The implementation of OHS and RM affecting the 
performance of workers is examined by using the descriptive analysis. The level of meeting a predetermined criterion is described by performing the percentage of the score's average for every statement variable's item. Table 6 shows the results of the analysis.

The indicator that has the highest mean on the Occupational Health (X1) is the following statement: "Emergency treatment is available in case of accident in construction site" (X14). The lowest mean value was that periodical health examinations are undertaken, especially with COVID 19 dispreading in Jordan (X13).

The indicator with the highest mean on OHS (X2) was the following statement: 'There are healthy and safety devices in my workplace" (X23). The lowest mean value on OHS (X2) was the following statement: "Only those with necessary equipment and assigned workers have access to likely and serious hazardous places in the organization" (X22)

The indicator with the highest mean in the RM (z) is the following statement: "Workers assigned to likely or serious hazardous tasks that are controlled regularly by internal audits to examine if they follow the set of procedures and instructions for the safety and health of workers in the organization" (Z5), while, the lowest mean value is the statement: "organization specifically takes into consideration the situation of groups that require special policies (elderly, disabled, etc.) during risk assessment" (Z4). The indicator with the highest mean on Worker Performance $(\mathrm{Y})$ is the following statement: "I always complete the tasks involved in the job description in my workplace" (Y5). At the same time, the lowest mean value is workload which is reasonably balanced in my organization (Y3).

Table 6. Descriptive Analysis

\begin{tabular}{|c|c|c|c|}
\hline No & Indicator & mean & percentage \\
\hline 1 & COVID 19 spreading :indicator (X11) & 3.72 & $74 \%$ \\
\hline 2 & First aid, accident management : indicator (X12) & 3.97 & $79 \%$ \\
\hline 3 & Medical examination : indicator (X13) & 3.67 & $73 \%$ \\
\hline 4 & Health care : indicator (X14) & 4.08 & $81 \%$ \\
\hline 5 & Work load : indicator (X21) & 3.83 & $76 \%$ \\
\hline 6 & Curative services : indicator (X22) & 3.72 & $74 \%$ \\
\hline 7 & Work safety equipment : indicator (X23) & 4.13 & $82 \%$ \\
\hline 8 & Quality assurance of $\mathrm{OH}$ processes, audits: indicator (X24) & 3.80 & $76 \%$ \\
\hline 9 & Errors in designs and specifications : indicator (Z1) & 3.71 & $74 \%$ \\
\hline 10 & Lack of training: indicator (Z2) & 4.31 & $86 \%$ \\
\hline 11 & safety procedure risk : indicator (Z3) & 3.97 & $79 \%$ \\
\hline 12 & Stockholder risk : indicator $(\mathrm{Z} 4)$ & 3.66 & $73 \%$ \\
\hline 13 & Environmental risk: indicator (Z5) & 4.38 & $87 \%$ \\
\hline 14 & Utilities risk : indicator $(\mathrm{Z} 6)$ & 3.87 & $79 \%$ \\
\hline 15 & Site access risk : indicator $(\mathrm{Z} 7)$ & 4.06 & $81 \%$ \\
\hline 16 & Security risk : indicator (Z8) & 4.11 & $82 \%$ \\
\hline 17 & Prioritizing : indicator (Y1) & 3.83 & $77 \%$ \\
\hline 18 & Skills: indicator (Y2) & 3.70 & $74 \%$ \\
\hline 19 & Ability: indicator (Y3) & 4.43 & $88 \%$ \\
\hline 20 & Quantity and quality work : indicator (Y4) & 4.33 & $86 \%$ \\
\hline 21 & working hours : indicator (Y5) & 3.65 & $73 \%$ \\
\hline 22 & Timeliness : indicator (Y6) & 4.07 & $81 \%$ \\
\hline 23 & Work equipment : indicator (Y7) & 3.71 & $74 \%$ \\
\hline 24 & Knowledge : indicator (Y8) & 3.84 & $76 \%$ \\
\hline
\end{tabular}


Table 7. Result of structure model

\begin{tabular}{|c|c|c|c|c|}
\hline hypothesizes & Coefficient & t-value & p-value & Result \\
\hline H1a[work safety (WS)have positive and significant influence worker performance] & 0.363 & 4.547 & 0.01 & Accepted \\
\hline $\begin{array}{l}\text { H1b [Occupational Health Safety }(\mathrm{OH}) \text { has positive and significant influence } \\
\text { worker performance] }\end{array}$ & 0.501 & 4.632 & 0.00 & Accepted \\
\hline H2a [work safety (WS)have positive and significant influence Risk Management] & 0.271 & 2.231 & 0.019 & Accepted \\
\hline $\begin{array}{c}\mathrm{H} 2 \mathrm{~b} \text { occupational health safety }(\mathrm{OH}) \text { has positive and significant influence on Risk } \\
\text { Management }\end{array}$ & 0.263 & 2.415 & 0.018 & Accepted \\
\hline $\begin{array}{l}\text { H3 Risk Management(RM) has positive and significant influence on workers } \\
\text { 'performance }\end{array}$ & 0.272 & 0.231 & 0.019 & Accepted \\
\hline
\end{tabular}

Table 8. MEDTERATION EFFECT (INDIRECT EFFECT)

\begin{tabular}{|c|c|c|c|c|}
\hline hypothesizes & Mediation & Coefficient & $\begin{array}{c}\text { Mediation of } \\
\text { nature }\end{array}$ & Result \\
\hline $\begin{array}{c}\text { H4a Risk Management(RM) plays a } \\
\text { meditation influence between work } \\
\text { safety and worker performance }\end{array}$ & Risk management & $\begin{array}{c}\text { Worker } \\
\text { performance }\end{array}$ & 0.179 & Partial mediation \\
\hline $\begin{array}{c}\text { H4b Risk Management plays a } \\
\text { meditation influence between } \\
\text { occupational health and worker } \\
\text { performance }\end{array}$ & Risk management & $\begin{array}{c}\text { Worker } \\
\text { performance }\end{array}$ & 0.151 & Partial mediation \\
\hline \begin{tabular}{c} 
accepted \\
\hline
\end{tabular}
\end{tabular}

\subsection{The Structure Model}

The structure model is evaluated by considering the coefficient value of the path parameter between the variables, and the results of test are presented in Table 7.

It showed the direct effect that is accepted as a whole $(\mathrm{H} 1 \mathrm{a}, \mathrm{H} 2 \mathrm{~b}$, and $\mathrm{H} 3)$ having a positive and significant effect. Work safety has a positive and significant on workers' performance, which is proved by the value of coefficient 0.363 with $\mathrm{p}=0.01$ alpha $=0.5$, hence, $(\mathrm{H} 1 \mathrm{a})$ is accepted, i.e., [0] WS has a positive and significant influence on workers' performance

Occupational health has a positive and significant effect on workers' performance, which is proved by the value of coefficient 0.501 with $\mathrm{p}=0.00$ alpha $=0.5$, therefore, $(\mathrm{H} 1 \mathrm{~b})$ is accepted, i.e., OHS has a positive and significant influence [0] on workers' performance

WS has a positive and significant effect on RM, which is proved by the value of coefficient 0.271 with $p=0.019$ alpha $=0.5$, hence, $(\mathrm{H} 2 \mathrm{a})$ is accepted, i.e., WS has a positive and significant influence on RM. Occupational health has a positive and significant effect [8] on RM worker performance, which is proved by the value of coefficient 0.263 with $p=0.018$ alpha $=0.5$, hence, $(\mathrm{H} 2 \mathrm{~b})$ is accepted; i.e., OHS has a positive and significant influence on RM.

RM has a positive and significant effect on workers' performance. It is proved by the value of coefficient 0.263 with $\mathrm{p}=0.018$ alpha $=0.5$, thus, $(\mathrm{H} 3)$ is accepted, i.e., $\mathrm{RM}$ has a positive and significant influence on workers' performance.

\subsection{Test of Mediation}

The structure model is evaluated by considering the coefficient value of the path parameter between the variables, and the result of the test is presented in Table 8 .

The test of the influence OHS variables on employees' performance on the initial model involving the RM mediation variable showed that OHS directly has a positive and significant effect on RM and worker performance. If the direct path coefficient estimate value is of $0.179 \mathrm{WS}$ and 0.151 of occupational health, then the RM has a positive and [0] significant effect on workers' performance. The mediation nature of OHS effect on workers' performance as being partially mediating, thus, there is evidence empirically to accept hypothesis (H4a). RM plays a mediation role between WS and workers' performance and $(\mathrm{H} 4 \mathrm{~b}) \mathrm{RM}$ plays a mediation role between occupational health and workers' performance accepted. Consequently, OHS results can affect RM directly and RM significantly affects workers' performance. OHS significantly affects workers' performance. The summary of the results is shown in Figure 2

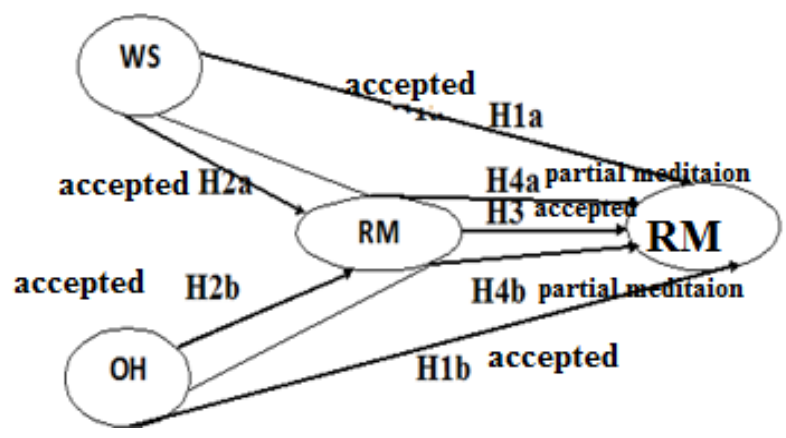

Figure 2. Result of structure model

However, this research finding supports Al-Refaie's [14] study that researched the implementation of OHS in construction companies and shows the same results, i.e., [14] OHS has a positive effect on improving employees' 
performance. Nonetheless, these results, contrary to Dababneh's [13] study which showed that the safety of the performance of the employee. [19] The results of this study are expected because construction labor can be exposed to many risks that affect the performance of the work and worker. From the answers of the participants, OHS and RM affected the performance of workers positively because the location of the work is open and much work can be performed manually. Hence, the workers need protection since they can be exposed to several risks. For example, the safety helmets are worn on the head to protect the worker from the scorching heat of the sun and to focus more on open work; if workers do not wear safety helmets, they are troubled by the heat of the sun on free labor. Rubber boots are dressed in a mixing-work and manual excavating so that the workers are protected from foot injuries. According to the respondent, at around $25 \%$ of the mixing-work progress, workers are injured when using shoes. There are other social and environmental aspects that influence the results that have not been considered such as income and wealth, life style, transportation, social culture, and effect of public policy. There is a need for similar studies to be conducted, especially in Jordan, since no research has examined these aspects up to now. [4] The analysis methods employed by this research can be applied to other case studies such as road construction labor in Jordan and can be applied in other developing countries like Iraq

\section{Conclusions}

The OHS implementation and RM factors affect workers' performance as follows: 1 . The most important factors of implementing OHS which affect the workers' performance are as follows: Occupational Health Factor (X1) with the highest result is the following statement: "Emergency treatment is available in case of accident in construction site" $\mathrm{X} 1.4=4.08$, with a percentage of 81 (Very Good.);

1. Work Safety factor (X2) with the highest result is the following statement: "There are healthy and safety devices in my workplace" $(\mathrm{X} 2.3)=4.13$, with a percentage of 82 (Very Good);

2. The most important factor of RM that affects the performance of workers is as follows. Risk management factor $(\mathrm{Z})$ with the highest result is the statement that workers assigned to likely or serious hazardous tasks that are controlled regularly by internal audits to examine if they follow the set of procedures and instructions for the safety and health of workers in the organization $(\mathrm{Z} 5)=4.38$ with a percentage of 87 . Worker Performance factor $(\mathrm{Y})$ with the highest result is the following statement: "I always complete the tasks involved in the job description in my workplace." (Y5) $=4.43$, with a percentage of 88 (Very Good)

3. The implementation of RM affected the performance of workers. RM has a positive effect on workers' performance because the location of the work is open and much work can be performed manually.

4. The implementation of OHS affected the performance of workers. OHS has a positive effect on workers' performance because the location of the work is open and much work can be performed manually.

5. RM plays a mediation role between the implementation of OHS on the construction site workers in Jordan and their performance. OHS can affect RM directly and then, RM significantly affects workers' performance accordingly. OHS significantly affects workers' performance.

6. The findings of this research are international and [3] up-to-date and are not applicable to certain regions only.

\section{The Contributions of This Research}

- Theoretically: The knowledge in the field of OHS would be increased concerning the effect of the implementation of OHS and RM programs and work motivation on worker productivity.

- Practically: The programs' extent which is focused on the construction projects can help relevant companies which are working in those fields. Employing OHS and RM programs can help in supporting the improvement of workers' performance other than construction services.

\section{REFERENCES}

[1] Aziz, Remon Fayek, and Sherif Mohamed Hafez. "Applying lean thinking in construction and performance improvement." Alexandria Engineering Journal "' vol. 52, No.4, pp. 679, 2013.

[2] Shehata, Mostafa E., and Khaled M. El-Gohary. "Towards improving construction labor productivity and projects' performance." Alexandria Engineering Journal " vol. 50. No 4, pp. 322, 2011.

[3] Ismail, Zubaidah, SamadDoostdar, and Zakaria Harun. "Factors influencing the implementation of a safety management system for construction sites." Safety science vol. 50. No. 3, pp. 420, 2012.

[4] Idoga P, E, Analysis of Factors Affecting the Health and Safety of Construction Workers, Conference: 5th International Project and Construction Management Conference At: Turkey, North Cypru. January Conference Series, Vol. 1375, 2020, Doi:10.1089/1772-6596/1675/1/01 2083. 
[5] Aderbag, A. M., Saber KhElmabrouk, and A. M. Sherif. "Risk analysis related to costing and scheduling of construction projects." Proceedings of the International Conference on Industrial Engineering and Operations Management, IEOM Society International, Bandung, Indonesia. Conference Series, Vol. 1375, 2018. Doi:10.1087/1749-6896/1375/1/012090 2018.

[6] Abdulnabi, ER Hassan Mohamed, and V. C. Agarwal. "CLAIMS IN CONSTRUCTION PROJECTS "DESIGN ERRORS AND CHANGE ORDERS"." Technology vol 7.No 6 PP349, 2016.

[7] Ahmad, Iftikhar, Abdul Sattar, and Allah Nawaz. "Occupational health and safety in industries in developing world." Gomal Journal of Medical Sciences vol 14. No 4, pp. 23, 2016.

[8] Ting, Sim Nee, and Beatrice Jarit. "Sources of Risk and Related Effects in the Malaysian Construction Industry." Proceedings of the International Conference on Civil, Offshore and Environmental Engineering. Springer, Singapore, Conference Series, Vol. 1225, 2021. Doi:10.1044/1744-6595/1355/1/012060

[9] Panthi, Kamalesh, Lewis Waller, and Syed M. Ahmed. "Residential Construction Risk Management: Does It Happen in Real Life?." Collaboration and Integration in Construction, Engineering, Management and Technology. Springer, Cham, vol. 23. No 1, pp 476, 2021.

[10] Alkaissy, Maryam, et al. "Safety management in construction: 20 years of risk modeling." Safety science Vol. 129, No 1, PP 231, 2020.

[11] Zaid Alkilani, Suhair, Julie Jupp, and Anil Sawhney. "Issues of construction health and safety in developing countries: a case of Jordan." Australasian Journal of Construction Economics and Building, Vol. 13. No. 3, pp. 140, 2013.

[12] Khrais, Samir, et al. "Safety practices in Jordanian manufacturing enterprises within industrial estates." International journal of injury control and safety promotion vol 20 no .3 pp227, 2013.

[13] Dababneh, Awwad, Rami H. Fouad, and Abdul Jaleel Hamad Majeed. "Assessment of occupational safety and health performance indicators for Jordan." Journal of
Fundamental and Applied Sciences vol. 10, no 1, pp. 162, 2018.

[14] Al-Refaie, Abbas. "Factors affect companies' safety performance in Jordan using structural equation modeling." Safety science vol 57, no 11, pp. 169, 2013.

[15] Saputra, P.D. and Latief, Y. Development of Safety Plan Based on Work Breakdown Structure to Determine Safety Cost Precast Concrete Bridge Construction Projects. Case Study: Girder Erection with Launching Gantry Method. Civil Engineering and Architecture, 8, 3, 297-302, 2020.

[16] Abbasi, G. Y., M. S. Abdel-Jaber, and A. Abu-Khadejeh. "Risk analysis for the major factors affecting the construction industry in Jordan." Emirates Journal for Engineering Research vol 10.no 1, pp41, 2013.

[17] Alubaid, Faidhi A-RS, Rami HF Alhadeethi, and Anas J. Mohamed. "Assessment: The safety policy management for building construction companies in Jordan." Journal of Applied Engineering Science vol 18. No 1, pp 120, 2020.

[18] Fourry Handoko, Maranatha Wijayaningtyas, Imam H. A. Kusuma, Sutanto Hidayat, A. Ismail, Z. Abdullah, "The Occupational Health and Safety Effect on Road Construction Worker Performance," Civil Engineering and Architecture, Vol. 8, No. 5, pp. 750 - 759, 2020. DOI: 10.13189/cea.2020.080502

[19] Asep Setiawan, "Effect of Work Safety and Health Knowledge on Construction Workers in Cawang-Tomang Cengkareng Toll Road Projects". Civil Engineering and Architecture, Vol. 7(3A), pp. $1-6,2019$. DOI: 10.13189/cea.2019.071301.

[20] Sugiyo, no,. "Metode penelitian kuantitatif dan kualitatif dan R\&D." research method on quantitative qualitive and R\&D, bandung alpha beta, pp 30-130, 2010.

[21] Mangkunegara A. P. (Managing Company's Human Resource Development), 2nd ed. Bandung: PT. RemajaRosdaKarya, pp. 15-64, 2000.

[22] Hayduk, L. A. Structural equation modeling with LISREL: Essentials and advances. Jhu Press. 1987.

[23] Bollen, Kenneth A. "An alternative two stage least squares (2SLS) estimator for latent variable equations." Psychometrika vol. 61. No. 1, pp. 121, 1996. 